\title{
ANTICOAGULANT THERAPY IN THE TREATMENT OF VENOUS THROMBOSIS AND PULMONARY EMBOLISM IN ACUTE SPINAL INJURY
}

\author{
By DR Norval Watson \\ Spinal Injuries Unit, Lodge Moore Hospital, Sheffield
}

IN I968 I reported in our journal Paraplegia a survey of ten years experience in the management of acute spinal cord injury with special reference to the incidence of venous thrombosis and pulmonary embolism. In that report I came to several conclusions.

I. There was an average incidence of venous thrombosis of 12 per cent of total cases, of pulmonary embolism 5 per cent with a mortality of $\mathrm{I} \frac{1}{2}$ per cent with a great variation between individual years.

2. There was a higher incidence of venous thrombosis in complete lesions (I8 per cent) than incomplete (8 per cent).

3. There was a higher incidence in dorsal injuries than at other levels.

4. Mortality rates were similar at all levels.

5. The left leg was more often affected than the right leg.

6. Venous thrombosis occurred commonly about three weeks after injury.

7. Pulmonary embolism occurred often without previous warning of venous thrombosis, and the cases, which died suddenly from a massive embolism, usually died without warning.

8. Although venous thrombosis occurred at any age, the young and the very old were not in danger of death.

9. Venous thrombosis occurred at equal rates for men and women.

I0. There was no increased incidence of venous thrombosis where other injuries were associated with the spinal injury.

I I. Those cases subjected to major operation did not have an increased incidence of venous thrombosis.

I came to the conclusion that it would not be possible to reduce the mortality from pulmonary embolism unless anticoagulants were given prophylactically to all patients with spinal cord injury but that with our mortality rate this would not be justified.

In Sheffield it was decided that we should continue our policy of treatment with anticoagulants at the earliest and slightest indication of venous thrombosis and pulmonary embolism but not to use anticoagulants on a prophylactic basis. We realise that the prophylactic use of anticoagulants for all acute injuries is in practice at some centres, and since I expected most of these centres to report their methods and results at this meeting, I felt that the Sheffield centre could usefully report their results of the use of anticoagulants only for treatment of venous thrombosis and that our results could act as a control group.

I have therefore examined our incidence of venous thrombosis and pulmonary embolism for the five year period I968-1972 inclusive. Needless to say, all acute cases undergo the same routine paraplegic management of two-hourly turns, catheterisation, regular bowel evacuation and physiotherapy. All nursing and 
physiotherapy staff are on constant look-out for alteration in size and shape of limbs and it is unlikely that a venous thrombosis affecting the thigh veins would be missed. We have also been using the Sonicaid ultra-sound apparatus regularly but we find this instrument more useful to confirm a clinical diagnosis of venous thrombosis rather than as a routine screening procedure.

\section{TABLE I}

Yearly incidence

\begin{tabular}{|c|c|c|c|c|}
\hline Year & $\begin{array}{c}\text { Early } \\
\text { admissions }\end{array}$ & $\begin{array}{c}\text { Venous } \\
\text { thrombosis }\end{array}$ & $\begin{array}{c}\text { Pulmonary } \\
\text { embolism }\end{array}$ & Mortality \\
\hline 1968 & 44 & $6(13 \%)$ & $2(4 \%)$ & I $(2 \%)$ \\
1969 & 43 & II $(25 \%)$ & $6(13 \%)$ & I $(2 \%)$ \\
1970 & 37 & $7(18 \%)$ & $4(11 \%)$ & $-13 \%)$ \\
1971 & 59 & II $(18 \%)$ & $8(13 \%)$ & $2(3 \%)$ \\
1972 & 51 & $7(14 \%)$ & $4(8 \%)$ & $2(4 \%)$ \\
& 234 & $42(17 \%)$ & $24(10 \%)$ & $6\left(2 \frac{1}{2} \%\right)$ \\
$1958-67$ & & $\left(12 \frac{1}{2} \%\right)$ & $(5 \%)$ & $\left.1 \frac{1}{2} \%\right)$ \\
\hline
\end{tabular}

Table I reveals an incidence of venous thrombosis of $\mathrm{I} 7$ per cent and of pulmonary embolism Io per cent with a mortality of $2 \frac{1}{2}$ per cent.

These figures show an increase over the previous ten-year period, but this may be due to better diagnosis as we are keen to treat every case at the slightest indication.

\section{TABLE II}

Rates according to level and type of lesion

\begin{tabular}{|c|c|c|c|c|c|c|c|c|c|c|c|}
\hline & \multicolumn{3}{|c|}{ Cervical } & \multicolumn{3}{|c|}{ Dorsal } & \multicolumn{3}{|c|}{ Lumbar } & \multirow{2}{*}{ Complete } & \multirow{2}{*}{ Partial } \\
\hline & $\mathrm{C}$ & $P$ & Total & C & $\mathbf{P}$ & Total & $\mathrm{C}$ & $P$ & Total & & \\
\hline Admissions & 39 & 6I & 100 & 42 & 13 & 55 & 29 & 50 & 79 & IIO & I 24 \\
\hline $\begin{array}{l}\text { Venous } \\
\text { thrombosis }\end{array}$ & $\stackrel{9}{24} \%$ & $\stackrel{9}{\mathbf{4}} \%$ & $\begin{array}{l}\text { I } 8 \\
18 \%\end{array}$ & $\begin{array}{l}\text { IO } \\
24 \%\end{array}$ & $\begin{array}{l}\mathrm{I} \\
8 \%\end{array}$ & $\begin{array}{l}\text { II } \\
20 \%\end{array}$ & $\begin{array}{r}5 \\
17 \%\end{array}$ & $\begin{array}{c}8 \\
16 \%\end{array}$ & $\begin{array}{l}\text { I3 } \\
\text { 16\% }\end{array}$ & $\begin{array}{l}24 \\
22 \%\end{array}$ & $\begin{array}{l}18 \\
14 \%\end{array}$ \\
\hline $\begin{array}{l}\text { Pulmonary } \\
\text { embolism }\end{array}$ & $\begin{array}{c}6 \\
16 \%\end{array}$ & $\begin{array}{l}5 \\
8 \%\end{array}$ & $\begin{array}{l}\text { II } \\
\text { II } \%\end{array}$ & $\begin{array}{r}52 \\
12\end{array}$ & $\begin{array}{l}\circ \\
\circ \%\end{array}$ & $\begin{array}{l}5 \\
9 \%\end{array}$ & $\stackrel{3}{10} \%$ & $\stackrel{5}{10 \%}$ & $\begin{array}{l}8 \\
10 \%\end{array}$ & $\begin{array}{l}\mathrm{I} 4 \\
\mathrm{I} 2 \%\end{array}$ & $\begin{array}{l}\text { IO } \\
8 \%\end{array}$ \\
\hline Deaths & $\begin{array}{l}3 \\
8 \%\end{array}$ & $\begin{array}{l}2 \\
3 \%\end{array}$ & $\begin{array}{l}5 \\
5 \%\end{array}$ & $\begin{array}{l}\mathrm{I} \\
2 \%\end{array}$ & $\stackrel{\circ}{\circ \%}$ & $\begin{array}{l}\text { I } \\
2 \%\end{array}$ & $\begin{array}{l}\circ \\
\circ \%\end{array}$ & $\begin{array}{l}\circ \\
\circ \%\end{array}$ & $\begin{array}{l}\circ \\
\circ \%\end{array}$ & $\begin{array}{l}4 \\
4 \%\end{array}$ & $\begin{array}{l}2 \\
2 \%\end{array}$ \\
\hline
\end{tabular}

Analysis of Table II shows:

I. A higher incidence of complications in complete lesions ( 22 per cent), than in incomplete lesions (I4 per cent generally). This confirmed our previous results. 
2. The incidence of pulmonary embolism bore a close relationship to the incidence of venous thrombosis.

3. Complications occurred equally at all levels but most deaths occurred in the cervical group and none in the lumbar group. This is at variance with our previous experience that the mortality rate was similar at all levels.

TABLE III

Site of thrombosis

$\begin{array}{lrr}\text { Right leg } & 5 \text { cases } & 12 \% \\ \text { Left leg } & 28 \text { cases } & 66 \% \\ \text { Pelvic or other veins } & 9 \text { cases } & 22 \%\end{array}$

Table III confirms our own previous experience.

TABLE IV

Date of onset of thrombosis

$\begin{array}{lrr}\text { Within I week } & 2 & 4 \% \\ \text { Within I month } & 35 & 85 \% \\ \text { Within 2 months } & 3 & 6 \% \\ \text { Within 3 months } & 2 & 4 \%\end{array}$

Table IV confirms our previous results that thrombosis occurs commonly two to three weeks after the injury.

\section{TABLE V}

Date of onset of pulmonary embolism

At same time as thrombosis

Within I week

Within I month

Within 3 months

$\begin{array}{rr}23 & 96 \% \\ 0 & 0 \% \\ 0 & 0 \% \\ \text { I } & 4 \%\end{array}$

In Table $\mathrm{V}$, the exception, all the cases of pulmonary embolism occurred without prior warning of venous thrombosis. As I have stressed before, the staff are on constant vigilance for this complication which is unlikely to be missed.

\section{TABLE VI}

Analysis of deaths

All six deaths occurred without previous warning

TABLE VII

Time of death

At I week

At 2 weeks

At 3 weeks

At 4 weeks

$\begin{array}{rr}\text { O } & 0 \% \\ 3 & 50 \% \\ 2 & 33 \% \\ \text { I } & 17 \%\end{array}$

Table VII confirms that major infarcts causing sudden death occur without warning in the second or third week after injury. 


\section{TABLE VIII}

Age of cases

Ages of venous thrombosis cases ranged from I4 to $7 \mathrm{I}$ years Ages of pulmonary embolism cases ranged from 17 to 69 years Ages of deaths ranged from 45 to 69 years.

Table VIII confirms our previous experience that while venous thrombosis and pulmonary embolism can occur at any age, the very young and the very old are seldom in danger of death.

TABLE IX

Sex incidence

\begin{tabular}{|c|c|c|c|c|}
\hline & $\begin{array}{l}\text { Admission } \\
\text { rate }\end{array}$ & $\begin{array}{l}\text { Venous } \\
\text { thrombosis }\end{array}$ & $\begin{array}{l}\text { Pulmonary } \\
\text { embolism }\end{array}$ & Death \\
\hline Male & $80 \%$ & $35(83 \%)$ & 2 I $(87 \%)$ & $4(67 \%)$ \\
\hline Female & $20 \%$ & $7(17 \%)$ & $3(13 \%)$ & $2(33 \%)$ \\
\hline
\end{tabular}

Table IX confirms our experience that the incidence of complications is equal in the sexes.

TABLE X

Associated injuries

\begin{tabular}{|l|c|c|}
\hline & $\begin{array}{c}\text { Associated } \\
\text { injury }\end{array}$ & No injury \\
\hline Venous thrombosis & $20(45 \%)$ & $22(55 \%)$ \\
Pulmonary embolism & I3 $(54 \%)$ & I I $(46 \%)$ \\
Death & $3(50 \%)$ & $3(50 \%)$ \\
\hline
\end{tabular}

Of 20 cases with associated injury

Four were head injuries

Six were chest injuries

Four were limb fractures

Six were multiple injuries

Table $\mathrm{X}$ confirms our previous experience that there was no increased incidence of venous thrombosis when an associated injury was sustained.

\section{TREATMENT}

The legs of every patient are measured at mid-thigh and mid-calf by the physiotherapy staff each day for the first vital month. The nursing staff who are 
turning the patient several times daily are also observing any alteration in the shape of the legs. On the first indication that venous thrombosis or pulmonary embolism has occurred or is even only suspected, then treatment is started with anticoagulants. Heparin is given intravenously for the first 24 hours until the oral drug Dindevan has taken effect. Treatment is continued for 12 weeks as a routine measure. In one case Warfarin had to be substituted for Dindevan as the prothrombin time could not be controlled with Dindevan. We have not had any complications from Dindevan therapy. We keep the prothrombin time between 30 and 50 per cent or two to three times normal. We have found by experience in previous years that treatment for three or six weeks only may still result in pulmonary embolism after treatment has ceased but that this has not occurred when treatment has been given for $\mathrm{I} 2$ weeks, which is now our standard procedure.

In this survey only one patient developed pulmonary embolism after treatment had been given for six weeks and stopped. Treatment was restarted.

There have been no deaths in any patient who has developed venous thrombosis and has been put on treatment. The six deaths occurred suddenly without any warning of venous thrombosis. Could they have been prevented by routine prophylactic anticoagulant therapy? It is perhaps relevant to note that three of the five quadriplegic patients who died were over 65 years of age, including the two incomplete lesions, and that two of the middle-aged patients who had complete lesions had bad psychiatric histories, the only patient with a dorsal injury having sustained this during a suicide attempt.

In our opinion, the low mortality rate in our series does not justify the routine prophylactic use of anticoagulants. 